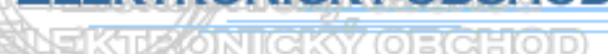

\title{
IDENTIFIKÁCIA REGIONÁLNYCH DISPARÍT VO VYUŽÍVANÍ TELEKOMUNIKAČNÝCH SLUŽIEB A INTERNETU
}

\begin{abstract}
Alena Košt’álová*
Úvod

Vo využívaní telekomunikačných služieb a Internetu je možné pozorovat' viac či menej výrazné regionálne disparity. Ciel'om tohto príspevku je poukázat' na ne a to na základe prieskumu realizovaného v piatich okresoch Žilinského kraja (Bytča, Čadca, Kysucké Nové Mesto, Námestovo a Žilina). Respondentmi v realizovanom prieskume boli malé a stredné podniky so sídlom v spomínaných okresoch. Jedná sa o výsledky čiastkovej úlohy „Telekomunikačné služby“ a „Internetové služby“ v rámci Inštitucionálneho projektu č. I1607-140 riešeného na Žilinskej univerzite v Žiline.

Jedným z mnohých výstupov realizovaného prieskumu bola identifikácia regionálnych disparít vo využívaní telekomunikačných služieb a Internetu, pre identifikáciu ktorých je možné využit' viacero metód. Jednou z nich je metóda testovania nezávislosti umožňujúca prijat' štatistické rozhodnutie o hypotéze, ktorá vyjadruje nezávislost' dvoch znakov v regionálnom kontexte. V prípade potvrdenia štatisticky významnej závislosti je následne určený stupeň tejto závislosti pomocou niektorej z mier asociácie.

V prvej časti príspevku je preto stručne charakterizovaná metóda testovania nezávislosti dvoch kvalitatívnych znakov (podrobnejšie v [1]) a rovnako tiež mechanizmus stanovenia mier stupňa asociácie medzi dvomi znakmi (podrobnejšie v [1]). V d’alšej časti sú potom uvedené hypotézy, ktoré boli podrobené testovaniu nezávislosti a z nich vyplývajúce regionálne disparity vo využívaní telekomunikačných služieb a Internetu.
\end{abstract}

\section{Testovanie nezávislosti medzi hodnotami dvoch znakov}

Pri testovaní nezávislosti medzi hodnotami dvoch kvalitatívnych znakov je postup rozdelený do štyroch krokov. Prvým krokom je formulovanie hypotézy $\mathrm{H}_{0}$ oproti alternatívnej hypotéze $\mathrm{H}_{1}$. Druhým krokom je stanovenie hladiny významnostiTrefm krokom je výpočet testovacej štatistiky. Štvrtým krokom je porovnanie vypočítanej hodnoty $\chi^{2}$ s kritickou hodnotou a prijatie štatistického rozhodnutia.

\section{1. krok - Formulovanie hypotéz}

Nulová hypotéza $\mathrm{H}_{0}$ vyjadruje nezávislost' premenných. Oproti tomu alternatívna hypotéza $\mathrm{H}_{1}$, ktorej pravdivost' väčšinou chceme dokázat', najčastejšie vyjadruje štatistickú závislost' premenných. Pravdivost' alternatívnej hypotézy sa dokazuje vždy iba nepriamo a to tak, že ukážeme, že nulová hypotéza je nepravdepodobná a alternatívna (jediná zostávajúca)

\footnotetext{
* Ing. Alena Koštálová, PhD., Žilinská univerzita v Žiline, FPEDAS, Katedra spojov, Univerzitná 8215/1, 01026 Žilina, tel.: +421 41513 3143, e-mail: Alena.Kostalova@fpedas.uniza.sk
} 
je teda pravdepodobná. Nezávislost' je overovaná chí-kvadrát testom. Chí-kvadrát rozdelenie má prvoradý význam pri analýze závislosti v asociačných a kontingenčných tabul'kách [2].

\section{2. krok - Stanovenie hladiny významnosti $\alpha$}

Alfa $(\alpha)$ sa tradične stanovuje na hodnotu $5 \%(=0,05)$, alebo $1 \%(=0,01)$. Odchýlky, ktoré sa vyskytujú s pravdepodobnost'ou menšou ako je zvolená hladina významnosti, sa nazývajú štatisticky významné (signifikantné) pri zvolenej hladine významnosti. V príspevku sa uvažuje s hladinou významnosti $\alpha=0,05$.

\section{3. krok - výpočet testovacej štatistiky $\chi^{2}$}

Pomocou testovacej štatistiky sa zistí štatistická hodnota testu chí-kvadrát pre empirické a teoretické početnosti. Vypočíta sa zo vzorky, ktorá má za predpokladu pravdivosti nulovej hypotézy príslušné rozdelenie pravdepodobnosti (chí-kvadrát).

\section{4. krok - prijatie štatistického rozhodnutia o hypotéze $\mathrm{H}_{0}$}

Pri prijímaní štatistického rozhodnutia o hypotéze $\mathrm{H}_{0}$ je potrebné sa riadit' nerovnost'ou medzi vypočítanou hodnotou testovacieho kritéria a príslušnou kritickou hodnotou, ktorou je vymedzená kritická oblast' pre chí-kvadrát. Môžu nastat' dva prípady [3]:

$\checkmark$ vypočítaná hodnota testovacieho kritéria je väčšia alebo rovná ako kritická hodnota. Nulovú hypotézu zamietame, alternatívna hypotéza je preukázaná. Sledovaný rozdiel je štatisticky významný. Medzi premennými existuje vzt’ah.

$\checkmark$ vypočítaná hodnota testovacieho kritéria je menšia ako kritická hodnota. Nulovú hypotézu nemožno zamietnut'. Sledovaný rozdiel nie je štatisticky významný. To však neznamená, že nulová hypotéza je správna. Nemáme iba dostatok dôkazov na to, aby sme mohli tvrdit', že medzi premennými existuje vzt’ah.

\section{Miery stupňa závislosti medzi dvomi znakmi}

Pomocou chí-kvadrát testu je možné získat' informáciu, či vzájomnú závislost' medzi hodnotami kvalitatívnych znakov A a B je možné považovat' za štatisticky významnú alebo nie. V prípade štatistickej významnosti tejto závislosti je však možné jej stupeň hodnotit' len nepriamo. Priame hodnotenie stupňa vzájomnej závislosti je možné pomocou mier asociácie [2], [4], ktoré sú odvodené od vypočítanej hodnoty testovacieho kritéria - $\chi^{2}$ hodnoty. Sú to Phi koeficient, Kontingenčný koeficient C, Cramerovo V a Čuprovov koeficient $\tau$. Čím viac sa hodnota miery asociácie blíži k 0, tým je stupeň nezávislosti medzi hodnotami znakov A a B vyšší.

\section{Regionálne disparity vo využívaní telekomunikačných služieb a Internetu}

Východiskom pre stanovenie hypotéz, vyjadrujúcich nezávislost' znakov A a B v regionálnom kontexte, boli výsledky dvojstupňového triedenia hodnôt štatistického súboru získaných marketingovým prieskumom podl'a okresu v ktorom respondent sídli. Pre každú identifikovanú dvojicu kvalitatívnych znakov, ktorá mala byt' podrobená testovaniu nezávislosti, bola stanovená nulová hypotéza o nezávislosti znakov a predpoklad, či bude zamietnutá, alebo ju nebude možné zamietnut'. V prípade zamietnutia nulovej hypotézy bol následne stanovený stupeň vzájomnej závislosti znakov pomocou niektorej z mier asociácie.

Pre účely skúmania vzt’ahu medzi znakmi A a B, kedy znak A patrí do celku „Telekomunikačné služby“, prípadne do celku „Internetové služby“ a znak B je „Okres v ktorom respondent sídli“, boli stanovené nižšie uvedené hypotézy. Pri každej hypotéze je uvedený výsledok štatistického rozhodnutia spolu so stupňom vzájomnej závislosti znakov. 


\section{$H_{0}$ : Výber poskytovatel’a telekomunikačných služieb respondentom nezávisí od toho, v ktorom okrese sídli}

(predpoklad: $H_{0}$ bude zamietnutá)

Regionálne disparity sa nepotvrdili. Výber poskytovatel'a telekomunikačných služieb teda nezávisí od toho, v ktorom okrese respondent sídli. Možno konštatovat', že územná dostupnost' prístupových a kontaktných miest jednotlivých poskytovatel'ov telekomunikačných služieb je v rámci sledovaných okresov dostatočná.

\section{$H_{0}$ : Frekvencia využívania vybranej telekomunikačnej služby respondentom nezávisí od toho, v ktorom okrese sídli}

(predpoklad: $H_{0}$ bude zamietnutá)

Predpoklad zamietnutia nulovej hypotézy o nezávislosti skúmaných znakov nebolo možné potvrdit', ani vyvrátit' u viacerých telekomunikačných služieb (telefónna služba, audiokonferencia, videokonferencia a informačná služba AUDIOTEX) z dôvodu nesplnenia podmienky vhodnosti na testovanie ${ }^{1}$ vyjadrenej vzt'ahom (1). Predpoklad štatisticky významnej závislosti sa potvrdil len pri dvoch telekomunikačných službách, a to pri faxovej službe a pri službe prenos dát, kde pri obidvoch službách bola preukázaná slabá závislost' vo vzt'ahu k okresu v ktorom respondent sídli. Regionálne disparity sa nepotvrdili v prípade služby odkazová schránka.

\section{$H_{0}$ : Výška priemerných mesačných nákladov respondenta na telekomunikačné služby nezávisí od toho, v ktorom okrese sídli}

(predpoklad: $H_{0}$ bude zamietnutá)

Vzhl'adom k potvrdeným regionálnym disparitám vo frekvencii využívania niektorých vybraných telekomunikačných služieb bol stanovený predpoklad, že aj výška priemerných mesačných nákladov na telekomunikačné služby bude závisiet' od toho, v ktorom okrese respondent sídli. Tento predpoklad sa však nepotvrdil.

\section{$\mathrm{H}_{0}$ : Úroveň spokojnosti respondenta s telekomunikačnými službami nezávisí od toho, v ktorom okrese sídli}

(predpoklad: $H_{0}$ bude zamietnutá)

Dvojica znakov nebola vhodná na testovanie. Vymedzenie tried („úplne spokojný“, čiastočne spokojný“, „viac nespokojný ako spokojný“, „nespokojný“) neumožňovalo zlučovanie a následné splnenie podmienky vhodnosti na testovanie vyjadrenej vzt’ahom (1). Predpoklad teda nebolo možné potvrdit', ani vyvrátit'.

\section{$\mathrm{H}_{0}$ : Označenie vybranej charakteristiky telekomunikačných služieb respondentom za silnú stránku nezávisí od toho, v ktorom okrese sídli}

(predpoklad: $H_{0}$ bude zamietnutá)

Predpoklad zamietnutia nulovej hypotézy sa nepotvrdil nielen pri komplexnej charakteristike „kvalita“, ale aj pri všetkých čiastkových charakteristikách telekomunikačných služieb, ktoré sú jej súčast'ou. Čiastkovými charakteristikami, ku ktorým sa respondenti mohli vyjadrovat' boli: „dostupnost“", „cena“, „spol'ahlivost'“, „rýchlost“, „doplnkové služby“,

\footnotetext{
${ }^{1}$ Podl'a W. G. Cochrana, teoretických početností menších ako 5 môže byt' najviac 20 \%, ale aj tieto musia byt' väčšie ako 1 [5].

$$
P\left[\left(a_{i} b_{j}\right)_{0}<5\right] \leq 0,2 \wedge\left(a_{i} b_{j}\right)_{0}>1
$$

Táto podmienka je predpokladom, alebo tiež obmedzením pre použitie chí-kvadrát testu a výpočet testovacej štatistiky $\chi^{2}$ v tabul'kách s viac ako 2 riadkami a viac ako 2 stĺpcami. Obmedzenia pre použitie chí-kvadrát testu $\mathrm{v}$ tabul'kách s rozmermi $2 \times 2$ pozri podrobne $\mathrm{v}$ [1].
} 
„odbornost' zamestnancov“, „otváracie hodiny“ a „pokrytie signálom“. Znamená to, že respondenti považujú tieto charakteristiky za silné, prípadne slabé stránky telekomunikačných služieb bez ohl'adu na to, v ktorom okrese majú sídlo.

\section{$H_{0}$ : Predpokladaný trend vývoja telekomunikačných služieb nezávisí od toho, v ktorom okrese respondent sídli}

(predpoklad: $H_{0}$ nemožno zamietnut')

Dvojica znakov nebola vhodná na testovanie. Vymedzenie tried („trend je priaznivý“،, „trend je nepriaznivý“, „trend je bez zmeny“, „neviem posúdit“‘) neumožňovalo zlučovanie a následné splnenie podmienky vhodnosti na testovanie vyjadrenej vzt'ahom (1). Predpoklad teda nebolo možné potvrdit', ani vyvrátit'.

\section{$\mathrm{H}_{0}$ : Medzi tým, či a ako respondent uskutočňuje dátové prenosy a okresom v ktorom sídli nie je závislost'}

(predpoklad: $H_{0}$ bude zamietnutá)

Regionálne disparity, vo forme slabej závislosti, sa medzi uskutočňovaním dátových prenosov a okresom v ktorom respondent sídli potvrdili. Bližším skúmaním výsledkov dvojstupňového triedenia hodnôt štatistického súboru možno konštatovat', že variant „neuskutočňujeme dátové prenosy“ vyznačovali najmenej respondenti z okresu Námestovo. „Prenos dát cez siet“، je najmenej využívaný v okresoch Bytča a Čadca a najčastejšie ho využívajú v okrese Námestovo. Možnost' „prenosu dát iným nosičom“ využívajú v rovnakej miere respondenti v okresoch Bytča, Čadca a Kysucké Nové Mesto.

\section{$H_{0}$ : Medzi spôsobom, akým má respondent realizované pripojenie do siete Internet a okresom v ktorom sídli nie je závislost'}

(predpoklad: $H_{0}$ bude zamietnutá)

Medzi spôsobom pripojenia do siete Internet a okresom v ktorom respondent sídli bola preukázaná stredná závislost'. Potvrdenie regionálnych disparít v tejto oblasti vyplýva najmä z technických možností pripojenia respondenta do siete Internet v tom ktorom okrese.

\section{$\mathrm{H}_{0}$ : Výber operátora pre pripojenie do siete Internet respondentom nezávisí od toho, v ktorom okrese sídli}

(predpoklad: $H_{0}$ bude zamietnutá)

Ako bolo spomenuté vyššie, regionálne disparity sa nepotvrdili pri výbere poskytovatel'a telekomunikačných služieb. V tomto prípade, teda v prípade skúmania vzt'ahu medzi výberom operátora pre pripojenie do siete Internet a okresom v ktorom respondent sídli, sa regionálne disparity potvrdili. Bola preukázaná slabá závislost' medzi skúmanými znakmi.

\section{Záver}

Využitie štatistickej metódy testovania nezávislosti je jednou z možností identifikácie regionálnych disparít vo využívaní telekomunikačných služieb a Internetu. Aplikácia tejto metódy dáva možnost' jej využitia aj v iných dotazníkových prieskumoch zameraných na iné oblasti ako je využívanie telekomunikačných služieb a Internetu. Výsledky periodického prieskumu môžu byt' využité ako podklady pre návrhy a odporúčania za účelom zvyšovania kvality poskytovaných služieb, identifikácie regionálnych disparít a tiež za účelom segmentácie zákazníkov. Niektoré predpokladané regionálne disparity vo využívaní telekomunikačných služieb a Internetu sa potvrdili, iné poukázali na potrebu hlbšieho skúmania faktorov ovplyvňujúcich spotrebitel'ské rozhodovanie sa. 


\section{Literatúra}

[1] KOŠŤÁLOVÁ, A. Metodika testovania nezávislosti medzi kvalitatívnymi znakmi. In: Pošta, Telekomunikácie a Elektronický obchod [elektronický zdroj] : elektronický odborný časopis zameraný na problematiku poštových a telekomunikačných podnikov a oblast' elektronického obchodovania. ISSN 1336-8281. Roč. 5, č. 2 (2010), s. 29-38.

[2] CHAJDIAK, J. - KOMORNÍK, J. - KOMORNÍKOVÁ, M. Štatistické metódy. Bratislava: STATIS, 1999. ISBN 80-85659-13-1.

[3] LINCZÉNYI, A. Inžinierska štatistika. Bratislava: ALFA, 1974. 63-025-74.

[4] PACÁKOVÁ, V. a kol. Štatistika pre ekonómov. Bratislava: Edícia EKONÓMIA, 2003. ISBN 80-89047-74-2.

[5] KOŠŤÁLOVÁ, A. Marketingový prieskum využívania poštových a telekomunikačných služieb v regionálnom podnikatel'skom prostredí : doktorandská dizertačná práca. Žilina : Žilinská univerzita v Žiline, Fakulta PEDAS, Katedra spojov. 2009. 123 s.

\section{Grantová podpora}

JANKALOVÁ, M. a kol: Poskytovanie verejnej telefónnej služby a spôsoby jej hodnotenia v procese globalizácie. Grantový projekt VEGA MŠ SR a SAV č.1/0709/08, Žilinská univerzita v Žiline, FPEDAS, 2008. 